\title{
Morphological and Biochemical Analysis of Cicer arietinum L. under Paper Industrial Effluent Stress conditions
}

\author{
Rajat Chaudhary $^{1 *}$, Sonam Arya ${ }^{2}$, Shweta Tyagi ${ }^{1}$, Anurag Mishra ${ }^{2}$ and Vaishali ${ }^{2}$ \\ ${ }^{1}$ Department of Biosciences, D.A.V. (P.G. collage), Muzaffarnagar-251001 (U. P.), INDIA \\ ${ }^{2}$ Department of Biotechnology, Sardar Vallabhbhai Patel University of Agriculture and Technology, Meerut- \\ 250110 (U. P.), INDIA \\ ${ }^{*}$ Corresponding author. E-mail: rajatbio007@gmail.com.
}

Received: January 22, 2016; Revised received: August 12, 2016; Accepted: November 12, 2016

\begin{abstract}
To study the effect of paper industrial effluent on chickpea (Cicer arietinum L.) along with different concentration $(10 \%, 20 \% 40 \%, 60 \% 80 \%$ and $100 \%)$ and pure tape water as a control to compare the effect of paper industrial effluent for 7 days. Physico-chemical characteristics of paper effluent were analyzed in terms of $\mathrm{pH}$, colour, order temperature, DO, BOD, COD, Total hardness, carbonated hardness. All the parameters were found to be higher than the WHO prescribed discharge limits for effluent. The amount of carbohydrate, protein and reducing sugar were comparable with control, their amount were increased at $40 \%$ in effluent treated seeds. The chlorophyll content was increased simultaneously with effluent concentration. From this study it is clear that the industrial effluent rich in organic matter and plant nutrients are finding their use in agriculture as cheaper way of disposal.
\end{abstract}

Keywords: Paper industrial effluent, Physico-chemical characteristics, C. arietinum

\section{INTRODUCTION}

Industrialization is an important tool for the development of any nation. Today it has become a matter of major concern in the detoriation of the environment; with the rapid growth of industries the industrial waste water has increased tremendously (Amathussalam et al., 2002). Agriculture is the backbone of any economy has also been adversely affected by upsurge in the indiscriminate dumping and disposal of the wastes into land and watercourses. If excessive amount of these nutrition are absorbed by plants, the yield may get reduced and plant may die due to phytotoxicity (Singh and Sakal, 2001). Water resources are affected by industrial pollution extremely. Pollution caused by industrial effluents is a serious problem in throughout the world. The paper industerial effluent is having a higher amount of organic and inorganic elements. They contain higher contents of total hardness, total dissolved solids, biological oxygen demand, chemical oxygen demand, calcium, magnesium, sodium, iron and sulphate (Malik et al., 2014). Paper industrial effluent that has not been treated properly has an unpleasant odor when discharged into the environment. The effluents not only affect the plant growth but also degrade the soil properties when used for irrigation (Patel et al., 2004). So it is necessary to conduct experiments to find out the impact of these effluents on agricultural crops before they are recommended for irrigation. A laboratory experiment was designed to know the effect of different concentration (0-
$100 \%$ ) of paper industrial effluent on seed germination, growth, and biochemical content and yield of chickpea.

\section{MATERIALS AND METHODS}

The effluent was analyzed for its various physicochemical parameters as per the method of American Public Health Association (APHA, 1992). The industrial effluent was collected and then stored in dark room for future use. The paper industrial effluent was analyzed on C. arietinum with different concentration $(10 \%, 20 \%, 40 \%, 60 \%, 80 \%$ and $100 \%)$ at the germination and seedling growth after 7 days. The petriplates were irrigated with equal volumes of various concentration paper industrial effluent. Control was irrigated with equal volume of distilled water.

\section{Physico-chemical analysis}

Estimation of dissolved oxygen (DO): the paper effluent water sample were collected without bubbling in a $125 \mathrm{ml}$ BOD bottles, add $1 \mathrm{ml}$ of $36.4 \% \mathrm{MnSO}_{4}$ and $1 \mathrm{ml}$ iodine azide solution then the reagent is discharge below the surface. $1 \mathrm{ml}$ concentrated $\mathrm{H}_{2} \mathrm{SO}_{4}$ was added and shaken for completely dissolved, the brown precipitate was formed. Pipet the $50 \mathrm{ml}$ sample into a $500 \mathrm{ml}$ conical flask and titrate with $0.05 \mathrm{~N} \mathrm{Na}_{2} \mathrm{~S}_{2} \mathrm{O}_{3}$ until the iodine color become faint (Carpenter, 1965).

Estimation of biological oxygen demand (BOD): Take $125 \mathrm{ml}$ effluent sample in BOD bottles without bubbling. DO was estimated in one bottle by titration method and another bottle were added $1 \mathrm{ml}$ of $2 \% \mathrm{CaCl}_{2}$, 
$2 \% \mathrm{MgSO}_{4}$ and $2 \% \mathrm{FeCl}_{3}$. Bottles were kept for incubation at $27^{\circ} \mathrm{C}$ for 3 days and then DO was estimated in remaining bottles. BOD was estimated in $\mathrm{mg} / \mathrm{ml}$.

Estimation of chemical oxygen demand (COD): take $50 \mathrm{ml}$ of effluent sample and $5 \mathrm{ml}$ of $0.1 \mathrm{~N} \mathrm{~K}_{2} \mathrm{Cr}_{2} \mathrm{O}_{7}$ was added in each flask yellow orange color appeared and then kept in water bath at $90-100^{\circ} \mathrm{C}$ temperature for 15 $-20 \mathrm{~min}$. $5 \mathrm{ml}$ of KI solution and $10 \mathrm{ml}$ of conc. $\mathrm{H}_{2} \mathrm{SO}_{4}$ in flask was added, blackish red color appeared. Then titration is done with $0.1 \mathrm{~N} \mathrm{Na}_{2} \mathrm{~S}_{4} \mathrm{O}_{6}$ until the pale yellow color appeared. $1 \mathrm{ml}$ of starch solution were added in flask solution becomes blue. Then again titrated with $0.1 \mathrm{~N} \mathrm{Na}_{2} \mathrm{~S}_{4} \mathrm{O}_{6}$ until blue color disappear.

Estimation of total hardness: $100 \mathrm{ml}$ of effluent sample taken in a conical flask. Add $3 \mathrm{ml}$ ammonia buffer solution and 0.2 to $0.4 \mathrm{gm}$ of solid Eriochrome black T indicator. Titrated with standard EDTA red to blue and the amount of EDTA solution added is noted in $\mathrm{ml}$. Hardness was expressed in $\mathrm{mg} / \mathrm{ml}$.

\section{Morphological analysis}

Effect of industrial effluent on seed germination: For the analysis of seed germination and seedling growth, seed of uniform size, shape, color and weight were selected. Now seed were sterilized with $\mathrm{HgCl}_{2}$ solution, washed thoroughly with distilled water and kept in different concentration of industrial effluent separately. Seed simultaneously kept in distilled water, which constituted as control. After requisite imbibitions of 42 hours, germination was assessed by radical emergence (2-3mm).

Effect on 7 days seedling growth: Seeds were imbibed in different concentration of industrial effluent for up to 24 hours and were grown in separate petri plate for up to 7 days for germination. After 7 days, root shoot separated out from each other by cutting for the analysis. Five plants were collected from each treatment and were analyzed to determine the morphological parameters such as shoot length, root length, fresh weight and dry weight of the crop plant. The number of seeds germinated in each concentration was calculated.

\section{Biochemical analysis}

Estimation of total carbohydrate: Take10mg sample and $5 \mathrm{ml}$ of $2.5 \mathrm{NHCl}$ is added. Boiled in water bath up to 2-3 hours, cool at room temperature. Add $5 \mathrm{ml}$ of $2.5 \mathrm{NHCl}$ neutralized with sodium carbonate until the effervescence ceases. The volume is makeup up to $10 \mathrm{ml}$ by distilled water and centrifuged at 5000rpm for 5 minutes. Now, $0.2 \mathrm{ml}$ of supernatant was taken and add $0.8 \mathrm{ml}$ of distilled water, $4 \mathrm{ml}$ of Anthrone reagent was added and the solution is heated for 8 minutes in boiling water bath. Cooled rapidly in a freeze and then take O.D. at $\mathrm{A}_{630} \mathrm{~nm}$ (Hedge et al., 1962).

Estimation of reducing sugar: Take $50 \mathrm{mg}$ of dry sample and crushed in phosphate buffer. Centrifuge at $5000 \mathrm{rpm}$ for $5 \mathrm{~min}$, collect the supernatant and divided in to 3 replicates, makeup the volume $3 \mathrm{ml}$ by adding phosphate buffer. Add dinitrosalicylic reagent (DNS) in each replicate and placed in water bath at $100^{\circ} \mathrm{C}$ for 5-10minutes up to development of orange color. Cooled at room temperature and take O.D at $540 \mathrm{~nm}$ (Bernfeld, 1955).

Estimation of total protein: Take $50 \mathrm{mg}$ fresh plant sample was digested with $8 \mathrm{ml}$ phosphate buffer and centrifuged at $5000 \mathrm{rpm}$ for $5 \mathrm{~min}$. the $50 \mu \mathrm{l}$ of supernatant was taken from 3 replicates and $2.45 \mathrm{ml}$ of $0.1 \mathrm{~N}$ $\mathrm{NaOH}$ was added then $2 \mathrm{ml}$ of reagent $\mathrm{A}$ was also added and incubated at $37^{\circ} \mathrm{C}$ for 30 minutes. After incubation $5 \mathrm{ml}$ of reagent $\mathrm{B}$ is added and again incubated at $50^{\circ} \mathrm{C}$ for 5 minutes and then O.D. at $750 \mathrm{~nm}$ is noted. Calibration curve of BSA was useful for the determination of amount of protein (Lowry et al., 1951).

Estimation of chlorophyll content: Take $50 \mathrm{mg}$ of leaf were crushed in $5 \mathrm{ml}$ of chilled acetone $(80 \%)$ and centrifuged for 5 minutes. After centrifugation supernatant was collected and makeup final volume $5 \mathrm{ml}$ by acetone, then O.D was taken at two different wavelength at $645 \mathrm{~nm}$ and $663 \mathrm{~nm}$ (Arnon et al., 1949).

\section{RESULTS AND DISCUSSION}

Analysis of different parameter of paper industrial effluent as mentioned in table 1 . The paper industrial effluent was brownish in color with slightly acidic in nature ( $\mathrm{pH}$ 6.5) and odor of the effluent sample is very pungent. DO of effluent was $218.4 \mathrm{mg} / \mathrm{L}$. BOD and COD of effluent ware $110.4 \mathrm{mg} / \mathrm{L}$ and $411.8 \mathrm{mg} / \mathrm{L}$ respectively. The total hardness and carbonated hardness of effluent were $456.471 \mathrm{mg} / \mathrm{L}$ and $232.94 \mathrm{mg} / \mathrm{L}$ respectively.

The germination percentage of 24 hours treated effluent grown seeds are compared with the control plants. The germination percentage is decreased with increasing effluent concentration. No germination is found at $100 \%$ concentration of industrial effluent. The lowest percentage of germination is found in the $80 \%$ concentration of effluent treated seeds. The higher concentration of effluent is disrupted germination and seedling growth (Nagajyoti et al., 2008). The increase in germination percentage due to the reduction in level of toxic metabolites by dilution and better utilization of nutrients present in the effluent (Kannan, 2001). The reduction in germination percentage at higher concentrations may be due to the excess amount of minerals and nutrients present in the effluent (Kumar, 1999; Singh et al., 2006; Baskaran et al., 2009 and Sasikali and Poongodi,

Table 1. Physico-chemical properties of paper industrial effluent.

\begin{tabular}{lll}
\hline S.N. & Parameters & Reffluet \\
\hline 1. & Color & Brownish \\
2. & Odour & Pungent smell \\
3. & $\mathrm{pH}$ & 6.5 \\
4. & Dissolved & $218.4 \mathrm{mg} / \mathrm{L}$ \\
5. & Biological Oxygen Demand & $110.4 \mathrm{mg} / \mathrm{L}$ \\
6. & Chemical Oxygen Demand & $411.8 \mathrm{mg} / \mathrm{L}$ \\
7. & Total hardness & $456.47 \mathrm{mg} / \mathrm{L}$ \\
8. & Carbonated Hardness & $232.94 \mathrm{mg} / \mathrm{L}$ \\
\hline
\end{tabular}


Rajat Chaudhary et al. / J. Appl. \& Nat. Sci. 8 (4): 2099-2103 (2016)

Table 2. Biochemical parameters used on root, shoot, residual cotyledon (RC) and imbibed seed (IS) at different concentration of paper industrial effluent.

\begin{tabular}{llrrrrrr}
\hline Parameters & Planlets & \multicolumn{1}{c}{ Control } & $\mathbf{1 0 \%}$ & $\mathbf{2 0 \%}$ & $\mathbf{4 0 \%}$ & $\mathbf{6 0 \%}$ & $\mathbf{8 0 \%}$ \\
\hline Dry Weight (gm) & Shoot & 0.055 & 0.082 & 0.115 & 0.030 & 0.025 & 0.010 \\
& Root & 0.144 & 0.135 & 0.099 & 0.060 & 0.035 & 0.021 \\
& R.C. & 0.723 & 0.792 & 0.597 & 0.574 & 0.354 & 0.340 \\
Fresh Weight (gm) & Shoot & 1.335 & 1.448 & 0.776 & 0.765 & 0.685 & 0.432 \\
& Root & 0.483 & 0.663 & 0.160 & 0.285 & 0.148 & 0.840 \\
& R.C. & 2.292 & 1.032 & 1.582 & 1.651 & 1.492 & 0.854 \\
Carbohydrate (mg/gm) & Shoot & 0.56 & 0.26 & 0.41 & 0.69 & 0.35 & 0.18 \\
& Root & 0.26 & 0.18 & 0.27 & 0.24 & 0.47 & 0.75 \\
& R.C. & 2.66 & 1.63 & 5.00 & 3.12 & 3.39 & 0.75 \\
& Imbibe Seed & 2.07 & 2.44 & 2.25 & 1.54 & 1.09 & 0.75 \\
Reducing Sugar (mg/gm) & Shoot & 0.60 & 0.50 & 2.20 & 2.20 & 2.60 & 3.32 \\
& Root & 3.80 & 3.45 & 3.94 & 4.32 & 4.39 & 4.54 \\
& R.C. & 1.50 & 1.40 & 1.60 & 2.30 & 2.32 & 2.40 \\
Total protein (mg/gm) & Imbibe Seed & 0.83 & 0.80 & 0.81 & 0.98 & 0.81 & 0.99 \\
& Shoot & 1.16 & 3.60 & 3.56 & 5.52 & 3.08 & 2.89 \\
& Root & 4.08 & 0.48 & 0.42 & 0.40 & 0.76 & 0.76 \\
& R.C. & 1.84 & 0.46 & 0.62 & 0.40 & 0.60 & 0.46 \\
Chlorophyll (mg/gm) & Imbibe Seed & 1.32 & 1.42 & 1.52 & 1.62 & 1.48 & 1.32 \\
& Total Chl & 0.00220 & 0.00230 & 0.00402 & 0.00431 & 0.00469 & 0.00260 \\
& Chl a & 0.00096 & 0.00096 & 0.00229 & 0.00234 & 0.00276 & 0.00153 \\
& Chl b & 0.01263 & 0.01268 & 0.02602 & 0.02778 & 0.02971 & 0.01651 \\
\hline
\end{tabular}

2013). Reduction in seed germination percentage at higher concentration of effluent may be due to the higher amount of solids present in the effluent, which causes changes in the osmotic relationship of the seed and water the reduction in the amount of water absorption take place with results in to reduction of seed germination due to enhanced effluent salinity. (Chandrasekar et al., 1998; Priya Kaushik et al., 2005; and Sing et al., 2005).

The root length of $C$. arietinum seedlings were reduced in lower concentration of industrial effluent as compared to control. The maximum root length is observed $7.4 \mathrm{~cm}$ in control and the minimum root length 4.73 $\mathrm{cm}$ observed at $80 \%$ concentration of industrial effluent. In case of shoot, the maximum shoot length is observed $6.11 \mathrm{~cm}$ at $60 \%$ concentration and minimum shoot length $5.10 \mathrm{~cm}$ at $80 \%$ concentration. The reduction in shoot and root growth at higher concentration of effluent due to less amount of oxygen which might have restricted the energy supply and retarded the growth and development ( Kumar, 2000 and Baskaran et al., 2009).

The maximum fresh weight (FW) of shoot and root of C. arietinum seedlings is measured $1.44 \mathrm{gm}$ and 0.66 gm respectively at $10 \%$ concentration and the minimum FW of shoot and root $0.43 \mathrm{gm}$ and $0.84 \mathrm{gm}$ respectively at $80 \%$ concentration of industrial effluent, While in case of residual cotyledons (RC) maximum FW is measured $2.29 \mathrm{gm}$ in control and the minimum FW of RC $0.85 \mathrm{gm}$ at $80 \%$ concentration of industrial effluent. The maximum dry weight (DW) of shoot $C$. arietinum seedlings is measured $0.11 \mathrm{gm}$ at $20 \%$ concentration and the minimum DW of shoot $0.01 \mathrm{gm}$ at $80 \%$ concentration of industrial effluent. But in case of root maximum DW is measured $0.14 \mathrm{gm}$ in control and the minimum DW of root $0.02 \mathrm{gm}$ at $80 \%$ concentration of industrial effluent. In RC maximum DW is measured $0.79 \mathrm{gm}$ at $20 \%$ concentration and the minimum DW of RC 0.34 gm at $80 \%$ concentration of industrial effluent. The reduction in DW of plant materials may be due to the poor growth under effluent irrigation (Baskaran et al., 2009 and Malik et al., 2014). The seedling fresh weight and dry weight increased in the lower concentration and decreased in higher concentration of paper industrial effluent (Indra and Ravi mycin, 2009; Sasikali and Poongodi, 2013).

The maximum carbohydrate content in shoot of $C$. arietinum is observed $0.69 \mathrm{mg} / \mathrm{gm}$ at $60 \%$ concentration and minimum carbohydrate content in shoot 0.18 $\mathrm{mg} / \mathrm{gm}$ at $80 \%$ concentration of industrial effluent. But in root maximum carbohydrate content is observed $0.75 \mathrm{mg} / \mathrm{gm}$ at $80 \%$ concentration and minimum in root $0.18 \mathrm{mg} / \mathrm{gm}$ observed at $10 \%$ concentration of industrial effluent. In RC and Imbibe seeds (IS) minimum carbohydrate content are observed $0.75 \mathrm{mg} / \mathrm{gm}$ at $80 \%$ concentration and maximum carbohydrate content in RC and IS is $5.00 \mathrm{mg} / \mathrm{gm}$ and $2.44 \mathrm{mg} / \mathrm{gm}$ observed at $20 \%$ and $10 \%$ concentration of industrial effluent respectively. Total carbohydrate content is higher in waste water irrigated crops than control (Bamniya et al., 2010).

The maximum reducing sugar content in shoot, root, $\mathrm{RC}$ and IS of C. arietinum are observed $3.32 \mathrm{mg} / \mathrm{gm}$, $4.54 \mathrm{mg} / \mathrm{gm}, 2.4 \mathrm{mg} / \mathrm{gm}$, and $0.99 \mathrm{mg} / \mathrm{gm}$ at $80 \%$ concentration and minimum reducing sugar content in shoot, root, RC and IS are observed $0.6 \mathrm{mg} / \mathrm{gm}, 3.45$ $\mathrm{mg} / \mathrm{gm}, 1.4 \mathrm{mg} / \mathrm{gm}$ and $0.8 \mathrm{mg} / \mathrm{gm}$ at $10 \%$ concentration of industrial effluent.

The maximum protein content of $C$. arietinum in shoot 
and IS are observed $5.52 \mathrm{mg} / \mathrm{gm}$ and $1.62 \mathrm{mg} / \mathrm{gm}$ at $40 \%$ concentration and minimum protein content of shoot and IS $1.16 \mathrm{mg} / \mathrm{gm}$ and $1.42 \mathrm{mg} / \mathrm{gm}$ observed in control. While the maximum protein content in root and $\mathrm{RC}$ are observed $4.08 \mathrm{mg} / \mathrm{gm}$ and $1.84 \mathrm{mg} / \mathrm{gm}$ in control and minimum protein content in root and RC $0.4 \mathrm{mg} / \mathrm{gm}$ and $0.4 \mathrm{mg} / \mathrm{gm}$ observed at $40 \%$ concentration of industrial effluent. The increases in protein content of chickpea at lower concentration of industrial effluent were observed (Baskaran et al., 2009 and Jolly et al., 2012).

Chlorophyll estimation is one of the important biochemical parameter which is used as the index of production capacity. According to our results as mentioned, paper industrial effluent also affect the biosynthesis of chlorophyll a and $\mathrm{b}$ content, maximum reduction in $80 \%$ concentration which retard the growth of plant as well as leaf development. But in lower doses the chlorophyll content show increased amount and approximately double increment was observed in $60 \%$ concentration of effluent. Reduction in chlorophyll content induced by higher concentrations of effluent may be associated with mineral ions (Dutta and Biossay, 1997; Pragasam and Kannabiran, 2001; Singh et al., 2006; Baskaran et al., 2009 and Jolly et al., 2012). It may also due to the formation of enzymes chlorophyllase which is responsible for chlorophyll degradation (Neelam and Sahai, 1988).

\section{Conclusion}

The findings of the present study revealed that the paper industrial effluent at lower concentrations (10$40 \%$ ) promotes the growth and yield of $C$. arietinum but the higher concentrations reduced the same though phytotoxic nature of effluent. It can be concluded that the untreated paper industrial effluent reduced the crop growth. However, the stimulation of growth and yield were observed at lower concentration (10-40\%) of effluent. It is suggested that paper industrial effluent have to be diluted up to $40 \%$ level before it is used for irrigation. After dilution, the effluent characteristics will become within the prescribed limits and pollution load of the effluent decreased. The effluent at lower $(40 \%)$ concentration can serve as a liquid fertilizer for the cultivation of agricultural crops.

\section{REFERENCES}

Amthussalam, A., Abusbacker, M.N. And Jayabal, N. J. (2002). Growth and physiological activity of gree gram under effluent stress. Ind. Poll. Con., 118-119

APHA, AWWA and WPCF, (1992). Standard methods for the examination of water and wastewater 16 th eds. American Public Health Assoc., Washington, D.C.

Arnon, D.I. (1949). Copper enzymes in isolated chloroplastspolyphenoloxidase in beta vulgaris. Plant Physiol., pp: 24: 31

Bamniya, B.R., Kapasya, V. and Kapoor, C.S. (2010). Physiological and biochemical studies on the effect of waste water on selected crop plants. Biological Forum-An
International Journal, Vol. 2(2): 1-3

Baskaran, L., Sundaramoorthy, P., Chidambaram A.L.A. and Sankar Ganesh, K. (2009). Growth and physiological activity of greengram (Vigna radiata L.) Under Effluent Stress. Botany Research International, 2(2): 107-114

Bernfeld, P. (1955). Amylases and Method in Enzymol., Vol.1, PP:149., Academic Press USA (5).

Chandrasekar, W., Subramani, A. and Saravanan, S. (1998). Growth and physiological activity of green gram under effluent stress. J. Ind. Poll. Cont., 14-73

Carpenter, J.H. (1965). The chesapeake bay institute. technique for the Winkler oxygen method. Limnol. Oceanogr., 10: 141-143

Dutta, S.K. and Boissya, C.L. (1997). Effect of paper mill effluent on germination of rice (Oryza sativa L.) and growth behavior of its seedlings. J. Ind. Pollut., 13: 4147

Hedge, J.E. and Hofreiter, B.T. (1962). In carbohydrate chemistry 17 (Eds whistler RL and Be Millee, J.N) Academic press, New York

Indra, P. and Ravi Mycin, T. (2009). Germination changes of varieties of Vigna mungo L. under tannery effluent stress. Recent Research in Science and Technology, 1 (5): $217-222$

Jolly, Y.N., Islam, A. and Mustafab, A.I. (2012). Impact of dyeing industry effluent on soil and crop. Universal Journal of Environmental Research and Technology, 2 (6): $560-568$

Kannan, J. (2001). Effect of distillery effluent on crops plants. Adv. Plant. Sci., 14: 127-132

Kaushik, P., Garg, L. And Singh, V.K.B. (2005). Effect Effect of textile effluents on growth performance of wheat cultivars. Biores. Technol., 96-1189-1193

Kumar, A. (1999). Growth and physiological activity of green gram under effluent stress. Adv. Plant Sci., 2-261

Kumar, A. (2000). The effluents severally affect crop plants and soil. Adv. Plant Sci., 13-427

Lowry, O.H., Roesbrough, N.J., Farr, A. and Randall, R.J. (1951). Protein measurement with the folin phenol reagent. J. Biol. Chem., 193: 265-275

Malik, S., Bhati, H.P., Kumar, D. and Kumar, V. (2014). Germination and seedling growth of Vigna radiata L. under sugar mill effluent stress. International Journal Of Pharmaceutical Research And Bio-Science, 3(1): 5459

Nagajyoti, P.C., Dinakar, N., Prasadd, T.N.V.K.V., Suresh, C. and Damodharan (2008). Heavy metal toxicity: Industrial effluent effect on groundnut (Arachis hypogaea) Seedling. Journal of applied science research, 4 (1): $110-121$

Neelam, R. and Sahai, J. (1988). Effect of fertilizer factory effluent on seed germination, seedling growth, pigment content and biomass of Sesamum indicum Linn. J. Environ. Biol., 9: 45-50

Patel, K.P., Pandya, R.R., Maliwal, G.L., Patel, K.C., Ramani, V.P. and George, V. (2004). Heavy metal content of different effluents and their relative availability in soil irrigated with effluent waters around major industrial cities of Gujarat. Journal of Indian Society of Soil Science, 52: 89-94

Pragasam, A. and Kannabiran, B. (2001). Growth and physiological activity of green gram under effluent stress. Adv. Plant Sci., 14-547 
Rajat Chaudhary et al. / J. Appl. \& Nat. Sci. 8 (4): 2099-2103 (2016)

Sasikala, T. and Poongodi, N. (2013). Impact of dye effluent on seed germination of blackgram (Vigna mungo). Indian journal of applied research, 3(8): 47-48

Sing, S.P., Bhathanagar, M.K. and Singh, P.A. (2005). The reduction in seed germination at higher concentrations of salt. J. Indu. Poll. Cont., 21-163

Singh, P.K., Sharma, K.P., Kumar. S., Sharma, S. and Subhasini. (2007). Assessment of environmental contamination potential of distillery effluent using plant animal bioassays. Nat. Environ. Poll. Technol., 6: 63-74

Singh, A.P. and Sakal, R. (2001). Sewage sludge treated soils distribution and translocation of micronutrient cations in different plant species. Sustainable use of Chemicals in Agriculture, 2: 23-32

Singh, P.P., Mall, M. and Singh, I. (2006). Impact of fertilizer factory effluent on seed germination, seedling growth and chlorophyll content of gram (Cicer arietinum). $I$. Envron. Biol., 27: 153-156 